\title{
Biogeography of Polychaeta of the Eurasian North Polar Basin
}

\author{
I.A. Jirkov, M.K. Leontovich \\ Department of hydrobiology, Biological faculty, Moscow States University, 119991, Russia, \\ Moscow, Leninskije gory, house 1, building 12.e-mail: ampharete@yandex.ru
}

\begin{abstract}
Species ranges within the Eurasian North Polar Basin are investigated on the base of Russian collections and reliable literature data. It was shown that the real pattern of species distribution cannot be explained by the direct influence of abiotic factors. Species can be very abundant up to the boundary of their species range and totally absent in neighboring regions with very similar or the same conditions. Biogeographic boundaries can be situated in places without any sharp changes in abiotic conditions. Boundaries of biogeographic regions and species ranges can be stable for a century despite climatic changes. It is proposed to explain these phenomena by existence of large-scale ecosystems (bioms sensu Clements). It is proposed to split the Eurasian North Polar Basin into several biogeographic regions (= area of bioms).

How to cite this article: Jirkov I.A.., Leontovich M.K. 2012. Biogeography of Polychaeta of the Eurasian North Polar Basin // Invert. Zool. Vol.9. No.1. P.41-51.
\end{abstract}

KEY WORDS: species range, biogeography, North Polar Basin, Polychaeta.

\section{Биогеография полихет Евразийской части Северного Ледовитого океана}

\section{И.А. Жирков, М.К. Леонтович}

Кафедрагидробиологии Биологического факультета МГУ 119991, Россия, Москва, Ленинские zopbl, d. 1, cmp. 12.e-mail: ampharete@yandex.ru

РЕЗЮМЕ: Исследовано распространение видов в Евразийской части Северного Ледовитого океана на основе материалов отечественных коллекций и достоверных литературных данных. Показано, что положение границ ареалов видов не может быть объяснено непосредственным влиянием абиотических факторов. Виды могут быть массовыми вплоть до самой границы ареала и полностью отсутствовать в соседних районах со сходными или даже теми же абиотическими условиями. Границы ареалов видов и биогеографические границы могут проходить в районах, где отсутствуют резкие градиенты абиотических условий. Границы биогеографических регионов и видовых ареалов могут быть весьма стабильными веками, несмотря на климатические изменения. Предложено объяснить эти феномены существованием крупномасштабных экосистем. Предложено разделить Евразийский сектор Северного Ледовитого океана на несколько биогеографических регионов (ареалов ценотических систем).

Как цитировать эту статью: Jirkov I.A.., Leontovich M.K. 2012. Biogeography of Polychaeta of the Eurasian North Polar Basin // Invert. Zool. Vol.9. No.1. P.41-51.

КЛЮЧЕВЫЕ СЛОВА: ареалы видов, биогеография, Северный Ледовитый океан, полихеты. 


\section{Introduction}

Some species have wide ranges, some narrow. Areas of "crowing" of boundaries of species ranges are the biogeographic boundaries as there the distinct change in species composition occurs. There are two main hypotheses on the nature of boundaries of species ranges.

1. Limits of species ranges are determined primarily by the ability of species to survive in different abiotic conditions (Hengeveld, 1992; Brown, Lomolino, 1998). This idea has several circumstances which help to verify it: (1) species become more sparsely distributed and less common near the boundary of its range; (2) sharpness of biogeoraphic boundaries depends upon gradients of abiotic conditions, i.e. boundaries of species ranges are more dense in areas with sharp gradients and sparse or absent in areas without sharp gradients.

Upon first glance, biogeographic data confirm such a point of view: biogeographic boundaries usually coincide with climatic barriers (Brown, Lomolino, 1998). Briggs (1995) did not draw a biogeographic boundary between the North and Norwegian Seas, and included an area between the English Channel and the Rubachij Peninsula in the Eastern Atlantic Boreal Region. According to him there are no sharp biotic changes within the region, which is in agreement with data on temperature and salinity (Brattegard, Holthe, 1995).

2. Limits of species ranges are determined by the biomes of which they are part. Biomes are large scale ecosystems like prairies (Clements, 1916; Clements; Shelford, 1939; Razumovsky, 1999), they include as parts biocenoses sensu Mobius or ecosystems sensu Tensly. Longhurst (1998) used this term for biogeographic regions. This idea has several circumstances which help to verify it: (1) a species does not necessarily become more sparsely distributed and less common near the boundary of its range; (2) biogeographic boundaries should be very sharp and do not necessarily coincide with places of sharp gradients of abiotic factors.
This study has to aims (1) to investigate large-scale patterns in species distribution, and their correspondence between regions of sharp abiotic and biotic changes; (2) to propose subdivision of the North Polar Basin on the basis of species ranges.

\section{Material}

The present study is based on large Russian collections deposited in:

Department of Hydrobiology, Moscow State University, Russia;

Shirshov Oceanological Institute, Moscow, Russia;

Zoological Institute in St-Petersburg, Russia;

Zoological Museum of Moscow State University, Russia.

All the species distribution data from the above collections has been entered into a database. At the present time the database contains 16723 findings of 388 species. Ordinary species contain up to 964 points (Nothria hyperborea), whilst scarce species have only one or a few. Literature records, which include many incorrect identifications, were not used with the exceptions of Holthe (1986) and Kucheruk (1985). Further details of material examined and maps of ranges for all species can be found in Jirkov (2001).

For Decapoda unpublished data from the Ph.D. dissertation of V.I. Sokolov have been used. These data include all Decapoda species from the above mentioned collections.

The information on polychaetous distribution in British waters comes from the database of Marine Ecological Surveys Ltd., UK, I have had the chance to verify the identification of these records.

We limit our paper Eurasian North Polar Basin only, despite biogeography of the American part of the North Polar Basin should be very similar. However published data on Polychaeta distribution within this area almost completely absent. Collections investigated almost have no material from this region as well. 


\section{Methods}

At the present time there are a lot of methods for analyzing electronic datasets (cluster analysis, parsimony, analysis of endemicity, multidimensional and others). These methods group already selected and delimited regions, and these limitations of regions always should be done before applying them. In the simplest cases data is stored by stations used, but investigated data in museums are stored by species, and there are no lists of species by stations. Such a list cannot be prepared from our database as we cannot be sure that the whole sample has been stored, sometimes it is obvious that it is not the case. Further samples have been collected by very different sampling methods and such data cannot be compared. And above no one program is powerful enough to manage several thousands of samples. The usual way to make data available to program is to prepare a species list for selected localities or for areas limited by grid, or by any other artificial (to biological data) way, but it is not possible as for the first step we should be sure that area within such grid is uniform. In trying to do this we will meet the problems mentioned above plus the usual lack of data. For example for more than a century in the most sampled area, the Barents Sea, less than 1 sample per each 100 sq. $\mathrm{km}$ has been collected (in collections available).

Also all methods group regions by their similarity. In large scales the more similar communities of certain sediment will be (parallel communities in Petersen sense). Biome includes different communities (muddy, sandy and so on) connected in succession so parts of different biomes can be grouped instead of the whole unity. So appears a problem of biogeographical interpretation of the obtained results, as the method does not permit us to distinguish biogeographical borders and those of communities (stages of successions).

It was possible to use such methods for the regions we got, but their numbers were so small that there was no real necessity to do it.
Investigation of species ranges was made in several iterations:

(1) preparation of maps of species range of each species using PanMap (Diepenbroek et al., 2000);

(2) traditional typification of species ranges: "Typification is replacing an area of occupancy by an area of occurrence, using our knowledge about distribution of species with the most similar species ranges" (Nesis, 1985: 53). As different species can be members of different communities within the same biome, their species ranges can be slightly different and instead of a single boundary give zone of "crowding" boundaries of species ranges. A boundary common to all of them (= boundary of biome or biogeographic boundary) was drawn along outer edge of the crowding zone. Areas of different biomes should be complementary.

\section{Results and Discussion}

\section{Distribution of single species}

Nothria hyperborea (Fig. 1) is widely distributed along Pacific coasts, from Japan and California northwards, at shelf and slope depths. It is very common in the North Polar Basin, including the Norwegian shelf and slope, where sometimes it is the most abundant species of all Polychaeta and even of all macrobenthic taxa. At the southern extremity of its range in the North Atlantic, N. hyperborea is common, but is totally absent from the North Sea. Many polychaete species in families studied to date have similar distributions even though the same pattern is displayed by different families with different feeding and reproductive cycles and different substrate preferences so such distribution patterns cannot be explained by similarity in biology.

An even more striking example is the species range of Pectinaria granulata (Fig. 2). The species was described by Linnaeus in 1767 from Northern Europe. This is a shallow water species inhabiting depths usually less then $50 \mathrm{~m}$. Pectinaria granulata is very common in the North Pacific to the north of Washington State 


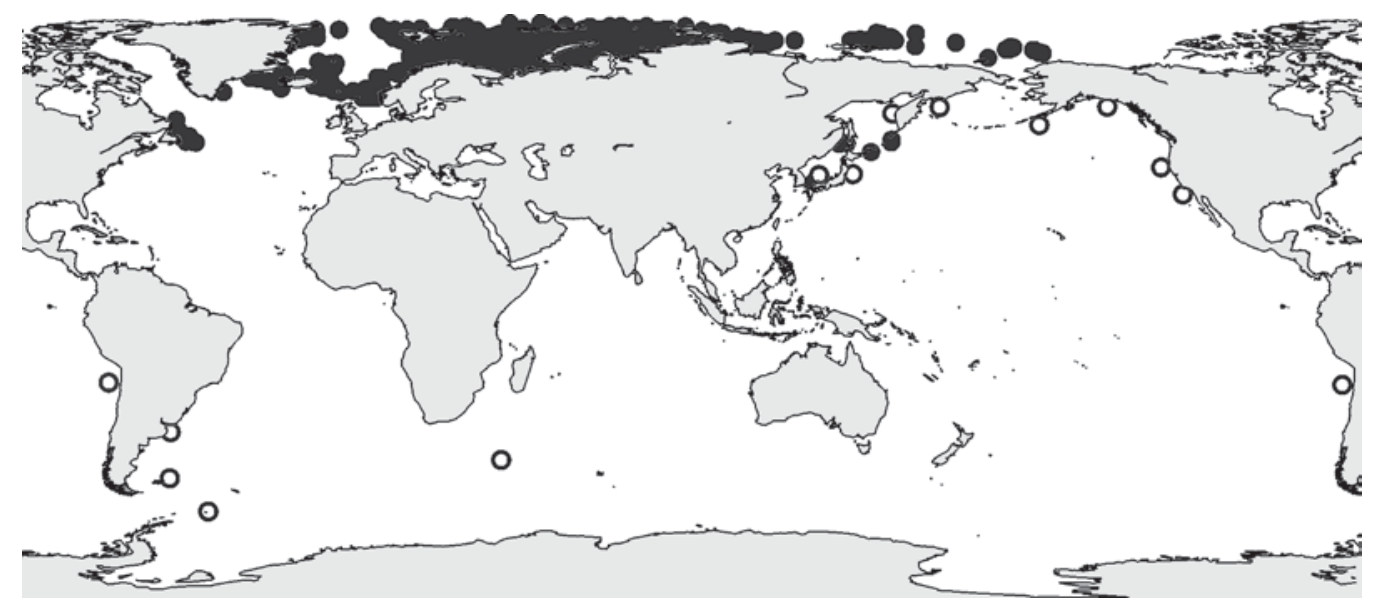

Figure 1. Nothria hyperborea species range.

Closed circles - specimen records from this study; open circles — data from Kucheruk (1985) and his pers. comm. On this and the following maps not all of the mapped samples can be found on the map because one sign may match several samples as they have been collected close together (or even at the same place) and can not be shown as separate signs.

Рис. 1. Ареал Nothria hyperborea.

Залитые кружки - изученный материал, незалитые - данные Кучерука (1985, и неопубликованные). На этой и следующих картах не все находки могут быть найдены, поскольку один значок может соответствовать нескольким пробам, если они были собраны вблизи друг от друга (или даже в том же месте) и они не могут быть поэтому показаны отдельными значками.

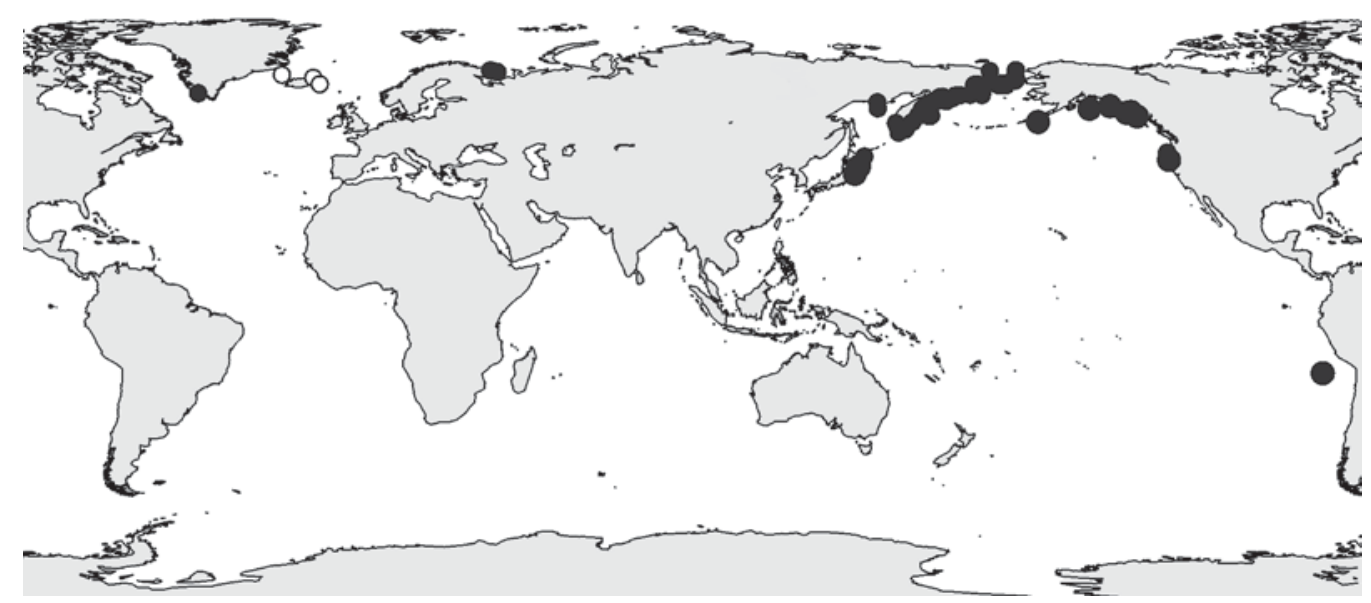

Figure 2. Species range of Pectinaria granulata.

Filled circles - samples with worms, outlined circles — subfossil tubes

Рис. 2. Ареал Pectinaria granulata.

Залитые кружки - пробы с червями, незалитые - субфоссильные трубки

and Japan. At some locations it is even a dominant member of the macrobenthos. In European waters it is very common and abundant in the Barents Sea along Russian coasts of Scandinavia. It is completely absent from Siberian seas except the Chuckchi Sea and is also absent in European waters from Norwegian waters and further to the south (Holthe 1986). Among pectinariids Pectinaria granulata is easily recognized, even by untrained workers, therefore, 
since no marine scientist for more than two centuries has collected the species outside this small area, we can have confidence that this distribution is correct. We are not aware of any abiotic factor or combination of factors which can explain such a distribution. Though there is no special investigation of the biology of Pectinaria granulata, all pectinariids have long lived planctonic larvae, however it does not help this species to disperse.

The examples provided show that species do not become more sparsely distributed and less common near the boundary of its range and boundaries of their ranges do not coincide with regions of sharp gradients of abiotic factors.

\section{Sharpness of boundaries}

This supposition was tested using material from the Barents Sea. Biogeographic subdivision of the Sea has been debated in the literature (Derjugin, 1915; Shorygin, 1928; Ekman, 1935, 1953; Gurjanova, 1951, 1957; Filatova, 1957; Zenkevitch, 1963; Golikov, 1963, 1980; Briggs, 1974; Nesis, 1982; Herman, 1989; Jirkov, in prep.). According to the most popular view on biogeography of the Barents Sea, the border between arctic and boreal regions is soft, its position changes according to climatic changes, with the distribution of arctic and boreal species overlapping.

Figure 3, incorporating all polychaete data, shows that this is not the case. According to Clements-Razumovskyi theory if we add other species nothing should change. Figure 4, showing all previous finds of Polychaeta species plus Decapoda, additional data verify the previous pattern.

Maps show that the real data on the distribution of arctic and boreal species support the concept of biomes. Arctic and boreal species belong to different biomes and have a common boundary and their ranges are complementary. The data used were obtained for the whole $20^{\text {th }}$ century.. For this period the intensity of the North Atlantic current inflow in the Barents Sea fluctuated considerably following climatic changes. If the boundary reflected these fluctuations of abiotic factors instead of a sharp bor- der we would have a more or less wide band. But it is not the case. Therefore, the location of biomes boundaries are more stable than the climate, at least within a century interval.

\section{Subdivision of the North Polar Basin}

The North Polar Basin has been a permanent subject of biogeographical interest since the first bigeographic schemes. One of the first schemes was published by Milne Edwards in 1837. He separated two regions in the Ocean: Celtic and Scandinavian. However real biogeographic subdivision of the Ocean begin in 1853 . In this year two schemes were published by Dana (1853) and Schmarda (1853). All of them independently add to Milne Edwards scheme of the Arctic region. The most important maps have since been published mainly by Russian scientists Deryugin (1915), Shorigin (1928), Gurjanova (1951), Filatova (1957), Zenkevitch (1947), Golikov (1963, 1980), Nesis (1982), subdivision of the North Polar Basin also was given by Ekman (1953) and Briggs (1974, 1995). Three published papers have been based exclusively on Polychaeta distribution (Jirkov, Mironov, 1985; Jirkov, 2001, 2010).

Authors of earlier schemes have only sporadic data on species distribution, so they drew biogeographic boundaries using mainly abiotic conditions, especially temperature and ice regimes. For example, the previously mentioned James D. Dana (1853) drew Arctic-Boreal boundary using an isocrime (line of mean temperature of the coldest month) equal to $44^{\circ} \mathrm{F}$ $\left(6,3^{\circ} \mathrm{C}\right)$. Only in last half of XX century did schemes become based on species distributions.

Using the method described above we identified several types of species ranges.

\section{Endemics of the North Polar Basin}

Deep high arctic (Fig. 5). There very few species with this type of distribution. However it is quite real and well delimited, as species within its species ranges are very abundant. Melinnopsis arctica, Hyalopomatus claparedii, Protis arctica, Paradiopatra pauli and Chauvinelia arctica have this type of distribution. 

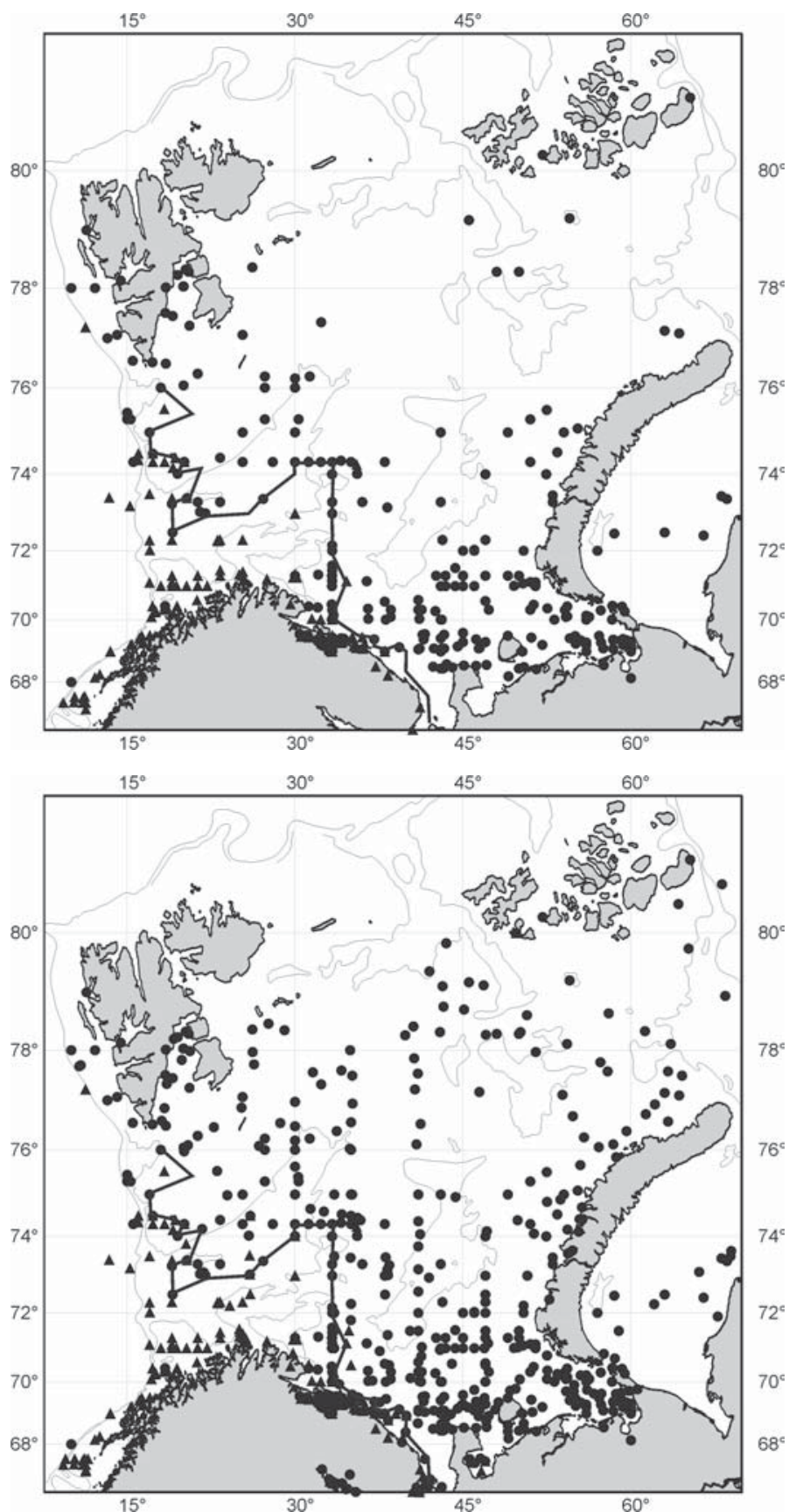

Figure 3. Boundary between arctic (circle) and boreal (triangle) biomes based upon Polychaeta. $1000-\mathrm{m}$ and $300-\mathrm{m}$ isobathes are shown

Arctic (including arctic-pacific) polychaetous species: Ampharete borealis, Amphicteis sundevalli, Axionice flexuosa, Branchiomma arctica, Clymenura polaris, Lanassa nordenkioeldi, Leaena ebranchiata, Lysippe labiata. Owenia polaris. Boreal polychaetous species: Amphitrite grayi, Aphrodita aculeata, Eunice pennata, Filograna implexa, Goniada maculata, G. norvegica, Hyalinoecia tubicola, Laetmonice filiformis, L. uschakovi, Neoleanira tetragona, Nephtys hystricis, Owenia borealis, Paradiopatraa fjordica, P. quadricuspis, Pectinaria auricoma.

Рис. 3. Граница межу арктическим (кружки) и бореальным (треугольники) ценотическими системами, основанная на распространении Polychaeta. Показаны изобаты 1000 м и 300 м.

Figure 4. Data for Figure 4 plus Decapoda.

Arctic Decapoda species: Sabinea septemcarinata, Spirontocaris phippsii, Scletrocrangonferox, $S$. boreas. Boreal Decapoda species: Hyas coarctatus, Lithodes maja, Pandalus montagui, Sabinea sarsi, Spirontocaris lilljeborgi.

Рис. 4. То же, но данные дополнены Decapoda.
Species with this type of distribution inhabit deep parts of the Arctic Ocean, with one very important exception: they are absent for the most part of the Nowegian Sea. Also they are absent west to Greenland. Species can be found on the shelf up to very shallow depth, but only near deep water. This is another good example of a distribution which can not be explained by abiotic conditions as they are the same in the deep Polar Basin, the Greenland Sea and in the 

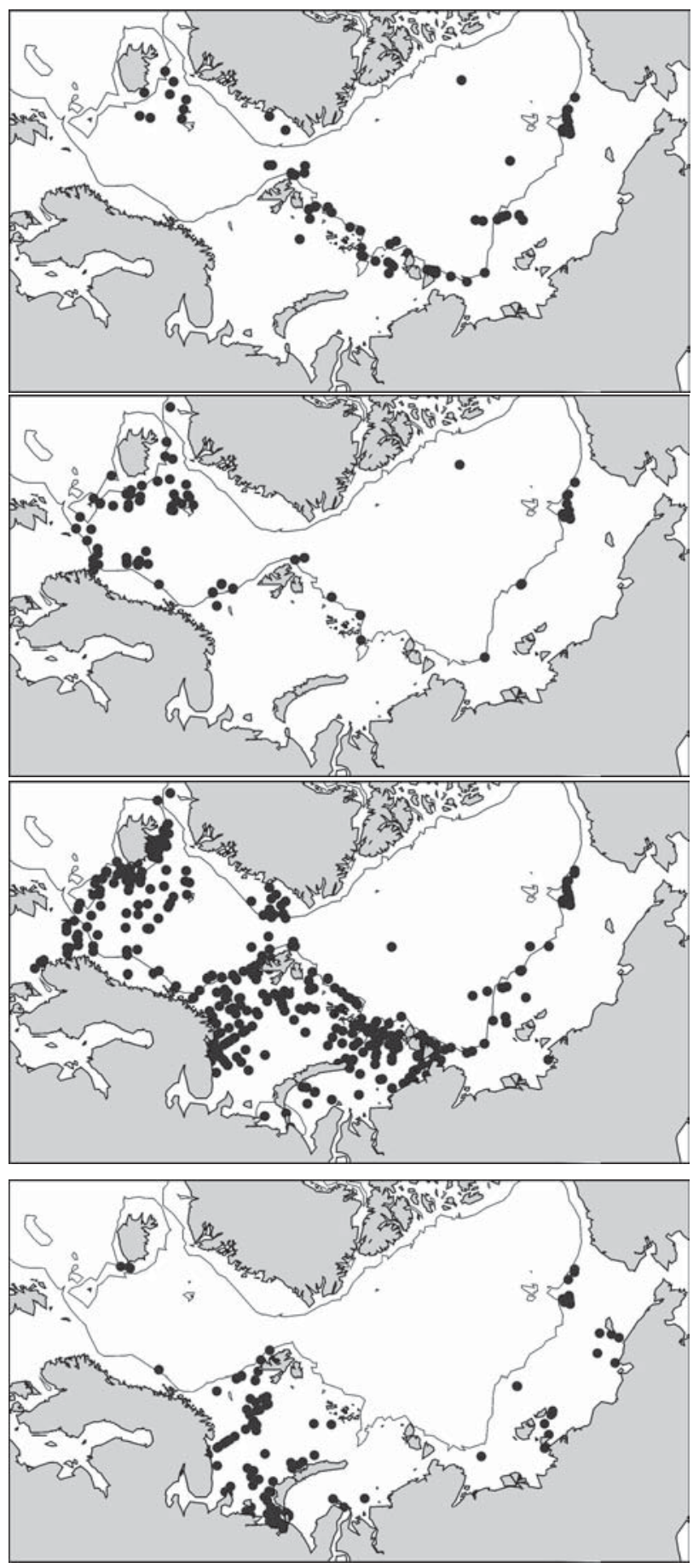

Figure 5. Species range of deep high arctic species. 500-m isobath is shown. Рис. 5. Ареал глубоководных высокоарктических видов. Показана 500-м изобата.

Figure 6. Species range of deep panarctic species.

Рис. 6. Распространение глубоководных панарктических видов.

Figure 7. Species range of eurybathic panarctic species.

Рис. 7. Распространение эврибатных панарктических видов.

Figure 8. Species range of shelf panarctic species.

Рис. 8. Распространение шельфовых панарктических видов.

Norwegian Sea. Some Macellicephalinae s.lato probably have this type of distribution, however their species ranges too poorly known.
Deep panarctic (Fig. 6). This type differs from the previous range by occurring in the whole Norwegian sea and west to Greenland, 
some species were found near Labrador and Newfoundland in the cold water. Examples: Nereis gracilis, Laonice blakei, Brada tzetlini, Polyphysia baffinensis, Grubianella klugei, Jasmineira schaudinni, Potamethus malmgreni, Phyllochaetopterus bhaudi, probably some Macellicephalinae s.lato.

Eurybathic panarctic (Fig. 7). This type differs from previous ranges by penetrating deep into shelf regions. However this does not mean that these species are shallow water. The shelf in the North Polar Basin is rather deep, deeper then in most of the Ocean. For example in the Barents Sea the shelf has up to $600 \mathrm{~m}$ depth. Some (very few) species penetrate into the deep part of the North Sea. Examples: Amage auricla, Amphicteis ninonae, Anobothrus laubieri, Maldane arctica, Nicomache quadrispinata, Polycirrus arcticus, Protula globifera, Pseudoscalibregma parvum, probably some Macellicephalinae s.lato.

Shelf panarctic (Fig. 8). Species with this type of distribution inhabit all shelves of the North Polar Basin, except Scandinavian and shelf of the east Greenland Sea which are influ- enced by the warm North Atlantic Current. Outside the North Polar Basin these species can be found along coast of Greenland and North America approximately south to Newfoundland. On the slope these species can be found in the Norwegian Sea only. Examples: Ampharete borealis, A. vega, Amphicteis sundevalli, Bispira crassicornis, Brada incrustata, B. rugosa, $B$. strelzovi, Branchiomma arctica, Bushiella kofiadii, Clymenura polaris, Euchone papillosa, Marenzelleria arctia, M. wireni, Micronephthys minuta, Owenia polaris, Paranaitis wahlbergi, Pterocirrus slastnikovi, Scalibregma robusta, Scolelepis burkovskii, Spio theeli.

The following types of distribution are usually called boreal species. However their distribution within the North Polar Basin differs so significantly that they should be separated at least in three types.

Species penetraiting into the North Polar Basin from the Atlantic

Some of these species are found in Pacific as well, but not in the Chuckchee Sea. To slightly simplify this group can be split into four groups.
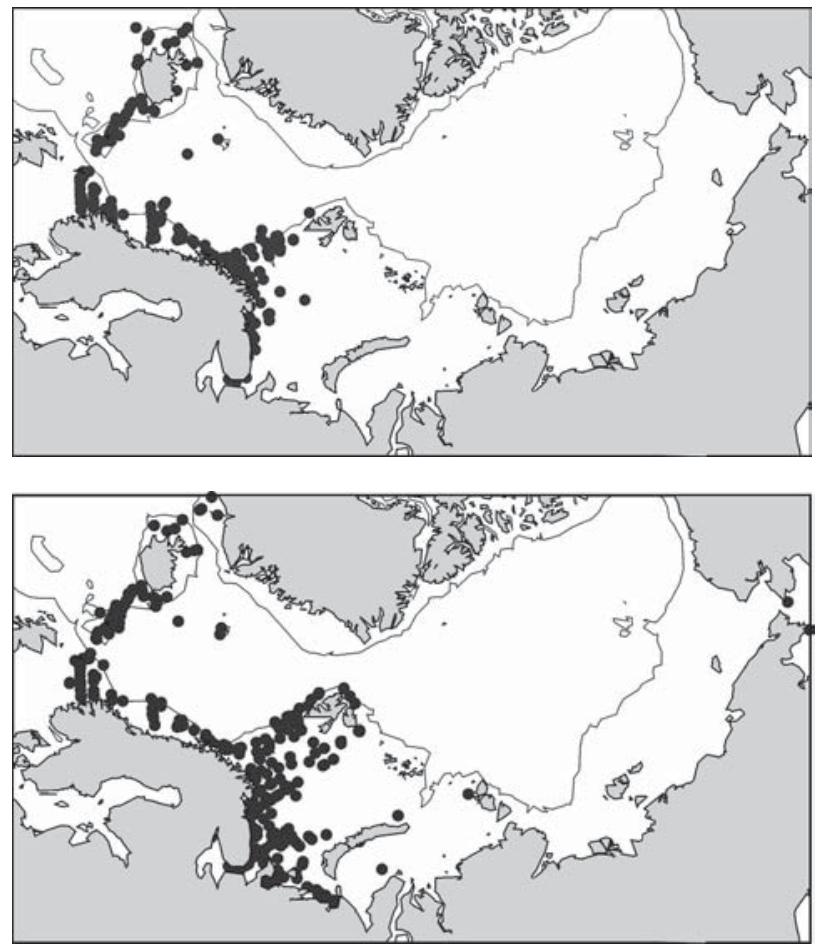

Figure 9. Species range of shelf atlantic boreal species.

Рис. 9. Распространение атлантических бореальных видов.

Figure 10. Species range of shelf atlantic wide boreal species.

Рис. 10. Распространение атлантических широко бореальных видов. 
Low boreal. All species with this type of distribution only slightly penetrate into the North Polar Basin, the main part of their species ranges lies outside it. As is the case with boreal species this type should be split into shallow water and shelf species, however the material at hand does not allow us to do it. Examples: Nothria africana, Laonice bahusiensis, Petta pusilla, Lysippides fragilis, Eclysippe vanelli, Lanice conchilega.

Shelf Atlantic boreal (Fig. 9). Species with this type of distribution inhabit the shelf and upper slope of the east Norwegian and Greenland Seas and the south-west corner of the Barents Sea. Examples: Amphitrite grayi, Aphrodita aculeata, Filograna implexa, Goniada maculata, G. norvegica, Hyalinoecia tubicola, Hydroides norvegica, Laetmonice filicornis, $L$. uschakovi, Neoleanira tetragona, Nephtys hystricis, Owenia borealis, Paradiopatra fjordica, P. quadricuspis, Pectinaria auricoma.
Shelf Atlantic wide boreal (Fig. 10). Penetrate in the North Polar Basin distinctly further to the East, up to the Kara Sea, than the previous group. Mapped: Amphitrite groenlandica, Asychis biceps, Hydroides noregica, Nephtys longosetosa, Nereis pelagica, Sosane wireni, Pista bansei, Polyphysia crassa.

There is a high probability that these two groups include pure shelf, slope and eurybath species. However within the North Polar Basin their species ranges are very similar, and differ almost exclusively to Atlantic parts. As we have no material from the North Atlantic we can not split them. However for the purposes of biogeographic subdivision of the North Polar Basin it does not matter how theirs ranges differ in the North Atlantic.

Shallow water boreal. Species with this type of distribution within the Atlantic sector can be found almost exclusively between the shore and tidal front (Longhurst, 1998) along

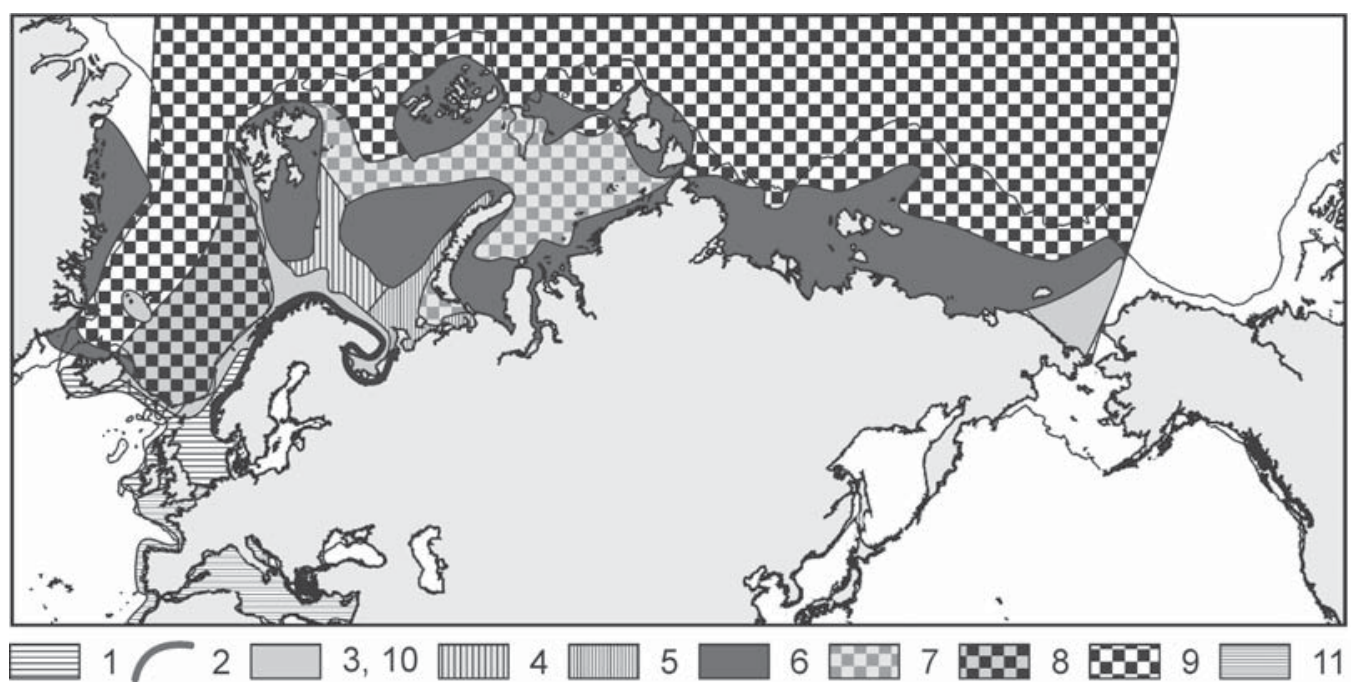

Figure 11. Biogeographic subdivision of the Eurasian North Polar Basin based upon polychaetous species ranges.

Provinces: 1 - Low boreal; 2 - Scandinavian shallow-water; 3 - Norwegian shelf; 4 - Barentz Sea transitional west; 5 - Barentz Sea transitional east; 6 - North Polar shelf; 7 - North Polar lower sublittoral-upper-bathyal; 8 Norwegian deep; 9 - Deep North Polar; 10 - Chuckchi shelf, 11 - Lusitanian.

Рис. 11. Биогеографическое районирование Евразийской части Северного Ледовитого океана, основанное на видовых ареалах полихет.

Провинции: 1 - Низкобореальная; 2 - Скандинавская мелководная; 3 - Норвежская шельфовая, Притихоокеанская; 4 - Баренцевоморская переходная западная; 5 - Барнецевоморская переходная восточная; 6 - Северополярная шельфовая; 7 - Северополярная нижнесублиторальная-батиальная; 8 - Норвежская глубоководная; 9 - Северополярная глубоководная; 10 - Чукотского шельфа, 11 - Лузитанская. 
the Scandinavian coasts, some also in the White Sea. Shallow Scandinavian region subdivides into at least three subregions: Norwegian, Murman and the White Sea. Species range of Pectinaria granulata (Fig. 2) is indicator of Murman Subregion. Examples: many Phyllodocidae and Spirorbidae, Alitta virens, Amphitrite figulus, Baffinia hesslei, Branchiomaldane labradorensis, Fabricia and other small Fabriciinae (Fabricia, Manayunkia), Micronephthys neotena, Pectinaria granulata, P. koreni, Pomatoceros triquiter.

Species penetraiting into the North Polar Basin from the Pacific

Shelf Pacific. Within the North Polar Basin species with this type of distribution inhabit the Chuckchi Sea. Examples: Glycinde wireni, Nephtys rickettsi, Ampharete sibirica.

Boundaries of these types of distribution are biogeographic boundaries, splitting the North Polar Basin into biomes (Figure 11). We consider these biomes as biogeographic provinces by analogy to data obtained by investigation of plant biogeography: "Province is the basic botanic-geographic unit, its floristic monolithic nature extremely high. While smaller subdivisions differ by several tens of species, provinces differ by hundreds" (Razumovsky, 1999: 63). The real picture is more complicated and cannot be shown by such a small map. A detailed map of biogeographic provinces of the Barents Sea will be published soon (Jirkov, in preparation).

As individual species usually are members of several biomes, an individual species range usually is the combination of these areas. Even some of the types of distribution described above are a combination of biome areas. For example, the species ranges of deep high arctic species are equal to area of the deep North Polar Province. The species ranges of deep panarctic species are equal to the area of the deep North Polar Province plus the area of the deep Norwegian Province. And finally, the species ranges of the eurybathic panarctic species are equal to the area of the deep North Polar, deep Norwegian and bathyal North Polar Provinces.
So the real number of the types of distribution are more numerous, but all of them are combinations of neighboring biogeographic regions. The only exception is the so called amphiboreal type of distribution, which includes the shelf Pacific and boreal Atlantic region(s). In any case boundaries of species ranges are the boundaries between Provinces.

Additionally, some species can be found along the biogeographic boundaries, while not being a member of any biomes separated by this boundary. For example, some shelf panarctic species can be found at the boundary separating Norwegian deep and Norwegian shelfProvinces and are not found within any of these Provinces.

\section{Acknowledgements}

We are very much in debt to Dr. N. Budaeva (Shirshov Oceanological Institute), Dr. G.N. Buzhinskaja and S. Potin (Zoological Institute in St-Peterburg) for kindly allowing me to investigate material for the present study. Also we wish to thank colleagues who kindly allowed the use of unpublished data on species distributions: Dr. V. Sokolov (VNIRO) on Decapoda, Emma Delduca (MES Ltd., UK), D. Hall and T. Worsfold (Thomson Unicomarine, UK) for data on Pectinariidae, N.V. Kucheruk for data on $N$. hyperborea. A special thanks to Emma Delduca (MES Ltd., UK), who corrected our English.

\section{References}

Brattegard T., Holthe H. (eds.). 1995. Kartlegging av egnede marine verneomarader i Norge. Tilradning fra radgivende utvalg. Untredning for DN 1995-3. Direktoratet for naturforvaltning. $174 \mathrm{p}$.

Briggs J.C. 1974. Marine Zoogeography. New York: McGraw-Hill Book Co. 475 p.

Briggs J.C. 1995. Global biogeography. Amsterdam Lausanne - New York - Oxford - Shannon - Tokyo: Elsevier. 454 p.

Brown J.H., Lomolino M.V. 1998. Biogeography. MA, U.S.A.: Sinauer Associates, Inc. 691 p.

Clements F.E. 1916. Plant succession: an analysis of the development of vegetation. Washington: Carnegie Inst. Publ. House. 512 p.

Clements F.E, Shelford V.E. 1939. Bio-Ecology. New York: J. Wiley \& Sons, Inc. I-VI+425 p.

Dana J.D. 1853. On the classification and geographical distribution of crustacea; from the report on crustacea 
of the United States exploring expedition, under Captain Charles Wilkes, U.S.N., during the years 18381842. Philadelphia: Sherman. P.1393-1592.

Derjugin KM. 1915. [Fauna of the Kola Bay and the conditions of its existence] // Mémoires de l'Académie Impériale des Sciences de Petrograd. VIII. Série, Classe Physico-mathétique. Vol.34. No.1. Petrograd. 929 p. [in Russian].

Diepenbroek M., Grobe H., Sieger R. 2000. PanMap, http://www.pangaea.de/Software/PanMap

Ekman S. 1935. Tiergeographie des Meeres. Leipzig: Akademische Verlagsgesellschaft. 542 S.

Ekman S. 1953. Zoogeography of the sea. London: Sidgwick and Jackson. 417 p.

Filatova Z.A. 1957. [Zoogeographical division of northern seas (by distribution of Bivalvia)] // Trudy Instituta Okeanologii AN SSSR. Vol.23. P. 195-215 [in Russian].

Golikov A.N. 1963. [Gastropoda of the genus Neptunea Bolten] // Fauna SSSR. Nov. Ser. No.85. Mollusks. Vol.5. No.1. 218 p. [in Russian].

Golikov A.N. 1980. [Mollusca Buccininae of the World Ocean] // Fauna SSSR, Nov. Ser. No.121. Mollusks. Vol.5. No.2. 508 p. [in Russian].

Gurjanova E.F. 1951. [Amphipoda of the USSR seas and neighboring water] // Opredeliteli po faune SSSR, izdavaemye Zoologicheskim Institutom AN SSSR. Leningrad: Nauka. Vol.41. 1033 p. [in Russian].

Gurjanova E.F. 1957. [Towards zoogeography of the Arctic Basin] // Materialy nablyudeniy nauchno-issledovatel'skikh stantsiy "Severniy Polus-3" and "Severniy Polus-4"1954/55 goda. Vol.1.P.343-355 [in Russian].

Hengeveld R. 1992. Dynamic Biogeography. Cambridge University Press. 249 p.

Herman Y. 1989 (ed.). The Arctic Seas - climatology, oceanography, geology, and biology. New York: Van Nostrand Reinhold Co. 888 p.

Holthe T. 1986. Polychaeta Terebellomorpha // Marine Invertebrates of Scandinavia. Norwegian University Press. Vol.7. 194 p.

Jirkov I.A. 2001. Polychaeta of the North Polar Basin Moscow: Yanus-K. 632 p. [in Russian].

Jirkov I.A. 2010. [Life on the seabed. Bio-geography and bio-ecology of benthos]. Moscow: KMK Scientific
Press. 453 p. [in Russian]

Jirkov I.A. (in preparation). Biogeography of the Barents Sea benthos

Jirkov I.A., Mironov A.N. 1985. [Contribution to zoogeography of Arctic polychaetes]// Trudy Instituta Okeanologii AN SSSR. Vol 120. P.137-151 [in Russian].

Kucheruk N.V. 1985. [Polychaeta of the genus Nothria (Onuphidae): diagnostic characters, species composition and distribution] // Issledovaniya fauny morei. Leningrad: Zoologicheskiy Institut AN SSSR. Vol.34 (42). P.83-87 [in Russian].

Linné C., von. 1767. Systema naturae per regna tria naturae, secundum classes, ordines, genera, species, cum characteribus, differentiis, synonymis, locis. 12th Edition. Vol.1. Pt.2. Holmiae [Stockholm], available online at http://www.biodiversitylibrary. org/item/ $83650 \# 5$

Longhurst A. 1998. Ecological geography of the sea. San Diego - San Francisco - New York - Boston London - Sydney - Tokyo: Academic Press. 399 p.

Nesis K.N. 1982. [Zoogeography of the World Ocean: comparison of zonation of the pelagic realm and regional subdivision of the shelf (concerning cephalopods)]//Kussakin O.G. (ed.). Morskaya biogeografiya: Predmet, metody, printsipy rayonirovaniya. Moscow: Nauka Press. P.114-134 [in Russian].

Nesis K.N. 1985. [Oceanic Cephalopoda: distribution, vital form, evolution]. Moscow: Nauka Press. 286 p. [in Russian].

Razumovskyi S.M. 1999. [Selected papers]. Moscow: KMK Scientific Press. 559 p. [in Russian].

Schmarda LK. 1853. Die geographische Verbreitung der Tiere. Abth. I-III, Wien: Gerold und Sohn.

Shorygin AA. 1928. [Die Echinodermen des Barentsmeeres] // Berichte des Wissenschaftlichen Meeresinstituts. Bd.3. H.4. 128 S. [in Russian, with German summary].

Zenkevitch L.A. 1947. [Fauna and biological productivity of the sea]. Leningrad: Sovetskaja Nauka. Vol.2. 588 p. [in Russian].

Zenkevitch L.A. 1963. Biology of the seas of the U.S.S.R. London: George Allen \& Unwin Ltd. 955 p.

Responsible editor K.G. Mikhailov 